\title{
Citrus Production, Constraints and Management Practices in Ethiopia: The Case of Pseudocercospora Leaf and Fruit Spot Disease
}

\author{
Asmare Dagnew $^{1^{*}}$, Derbew Belew ${ }^{2}$, Belayneh Admassu ${ }^{3}$ and Mohammed Yesuf ${ }^{1}$ \\ ${ }^{1}$ Ethiopian Institute of Agricultural Research (EIAR), Melkassa Agricultural Research Center, \\ Post Box No: 436, Adama, Ethiopia \\ ${ }^{2}$ Department of Plant Science and Horticulture, College of Agriculture and Veterinary Medicine, \\ Jimma University, Post Box No: 307, Jimma, Ethiopia \\ ${ }^{3}$ International Institute of Tropical Agriculture (IITA), Nairobi, Kenya
}

\begin{tabular}{|c|c|}
\hline Abstract & Article Information \\
\hline \multirow{2}{*}{$\begin{array}{l}\text { Citrus is economically important fruit crop in Ethiopia. However, its production is seriously } \\
\text { constrained by various diseases including Pseudocercospora leaf and fruit spot. Surveys }\end{array}$} & Article History: \\
\hline & Received : 28-04-2014 \\
\hline $\begin{array}{l}\text { were conducted between June } 2012 \text { and May } 2013 \text { in the main citrus production areas of the } \\
\text { country to assess the spread of the disease, and to determine its incidence and severity. A }\end{array}$ & : 16-05-2014 \\
\hline $\begin{array}{l}\text { total of forty-nine citrus orchards in twenty-eight districts were surveyed. Random sampling } \\
\text { techniques were used for data collection. The results showed that the disease had prevailed }\end{array}$ & Accepted : 18-05-2014 \\
\hline \multirow{4}{*}{$\begin{array}{l}\text { techniques were used tor data collection. The results showed that the disease had prevalled } \\
\text { and widely spread in the districts assessed in the wet humid areas of the south, southwest, } \\
\text { northwest, and north central parts, but not in the low altitude drier areas of the central rift } \\
\text { valley and the eastern region of the country. Accordingly, } 63.3 \% \text { of the orchards surveyed } \\
\text { were infected with the disease. The overall mean incidences of the disease on leaves of } \\
\text { sweet orange, mandarin, lemon and lime were } 36.2,21.5,17.1 \text { and } 16.3 \% \text { while disease }\end{array}$} & Key \\
\hline & Citrus \\
\hline & Leaf and fruit spot disease \\
\hline & Pseudocercospora \\
\hline \multirow{2}{*}{$\begin{array}{l}\text { severity ratings were } 2.6,2.3,2.0 \text { and } 1.7 \text {, respectively. Similarly, the average incidences } \\
\text { and severities on fruits were } 63.8,29.4,18.0 \text { and } 16.7 \% \text {, and } 4.0,3.0,2.0 \text { and } 2.0 \text {, in the } \\
\text { same order. However, disease incidences in the different orchards ranged from zero to } \\
76.7 \% \text { on leaves and from zero to } 100 \% \text { on fruits. Disease severity ratings also varied from }\end{array}$} & angolensis \\
\hline & Etr \\
\hline \multirow{2}{*}{$\begin{array}{l}\text { one to five on both leaves and fruits. In general, citrus orchards in the south and southwest } \\
\text { Ethiopia that are known to have high rainfall and humidity conditions were more severely }\end{array}$} & responding Author: \\
\hline & Asmare Dagnew \\
\hline & E-m \\
\hline & \\
\hline & \\
\hline
\end{tabular}

\section{INTRODUCTION}

Citrus (Citrus spp.) is one of the most economically important fruit crops grown by smallholders and commercial farmers in Ethiopia (Seifu, 2003; Kassahun et al., 2006; Mohammed, 2007). The total area coverage and the annual production of citrus were estimated 5,947 ha and 77,087 tons, respectively (CSA, 2011 and 2012). However, citrus production and productivity in Ethiopia is seriously threatened by various diseases including leaf and fruit spot disease (Eshetu, 1999; Seifu, 2003; Mohammed, 2007; Sisay, 2007), which is caused by the fungus Pseudocercospora angolensis (Carvalho and Mendes] Crous and Braun) (Seif and Hillocks, 1993; Kuate, 1999; Pretorius et al., 2003).

Pseudocercospora leaf and fruit spot (PLFS) disease has been reported as very destructive on citrus species in twenty-two tropical African countries and Yemen since its first observation in Angola and Mozambique in 1952 (Seif and Hillocks, 1993; Kuate, 1999; Mohammed, 2013). Due to the traditional trade of infected fruit and planting material, and the wind-borne dispersal nature of the fungal spores, PLFS disease is a potential threat to the Mediterranean basin and South Africa (Seif and Hillocks 1993; Kuate, 1999), and to the major producing American and Asian countries that supply more than $70 \%$ of the world's citrus production (Ndo et al., 2010).

The PLFS disease affects virtually all citrus species (Kirk, 1986; Kuate, 1999; Dewdney and Timmer, 2009). It became a serious citrus production constraint due to its impact on yield, quality and international trade. The disease occurs at all development stages and indiscriminately attacks leaves, fruits and young twigs. It causes devastating lesions that result in considerable premature leaf and fruit drop, and blemish fruits that remain on the tree. It can weaken trees and jeopardize 
Asmare Dagnew et al.,

production in severe conditions (Eshetu, 1999; Timmer et al., 2003; Mohammed, 2007). The disease can cause 50 to $100 \%$ yield loss; and a single lesion usually renders the fruit unsalable (Seif and Hillocks, 1993, 1999; Kuate et al., 2002; Chung and Timmer, 2009). It also affects the yield and quality of essential oils extracted from citrus fruit peels (Kuate et al., 2003).

In Ethiopia, characteristic symptoms of PLFS disease were first observed in the southern part in late 1980s (Yimenu, 1993). In early 1990s, similar disease symptoms were evident in the southwest areas. In some of these areas, entire fruit loss occurred and many farmers uprooted their citrus trees (Eshetu, 1997, 1999). Later, the disease was reported in the northwest part of the country (Yigzaw and Gelelbelu, 2002; Kassahun et al., 2006; Mohammed, 2007). Eshetu (1999) carried out a survey in southwest Ethiopia on sweet oranges and reported 100\% incidence, and $43 \%$ and $65 \%$ severity on leaves and fruits, respectively. Mohammed (2007) also conducted a survey in south, southwest and northwest Ethiopia and reported incidences that ranged from 64.5 to $98.6 \%$ on leaves and from 78.6 to $94.2 \%$ on fruits, and severity which varied from 52.4 to $84.0 \%$ on leaves and from 65.6 to $90.4 \%$ on fruits.

Knowledge on the pathogen population including its biology and ecology is required for appropriate monitoring and development of effective management strategies to combat the disease (Sisay, 2007; Amata et al., 2009). Management efforts are also based on the economic importance of the disease and its geographical distribution (Garnsey et al., 1998; Hughes et al., 2002; McDonald and Linde, 2002; Mohammed, 2007). However, the available information on the biology of the fungus and the epidemiology of PLFS disease is very limited (Eshetu, 1999; Kuate, 1999; Mohammed, 2007). In Ethiopia, there is no information on the current occurrence and distribution, and the extent of damage due to citrus PLFS disease. Therefore, this study was initiated to assess the present spread of PLFS disease, and to determine its incidence and severity in the major citrus growing areas of the country.

\section{MATERIALS AND METHODS}

\section{Survey Area}

Field surveys were conducted between June 2012 and May 2013 on various citrus species in the main citrus growing areas of Ethiopia. The geographic distribution of citrus orchards surveyed in the country is indicated in figure 1. A total of forty-nine citrus orchards and nurseries were surveyed in twenty-eight districts in the South Nations, Nationalities and People (SNNP), Oromia, Amhara and Somali Regional States, and the Dire Dawa City Administration where nearly the entire citrus production of the country is located. Citrus orchards, including backyards of small farmers, groves of Farmers' Association and Federal Prison Administration of Ethiopia, private and public medium and large scale commercial farms, fruit nurseries of the Ministry of Agriculture (MoA), and citrus foundation blocks in the research centers were surveyed.

\section{Assessment of Citrus Orchards in Ethiopia}

During the surveys, detailed questionnaire was used to collect general information about each citrus orchard from the farmers, development workers, horticulture experts, and researchers. Each citrus orchard considered in the

\section{Sci. Technol. Arts Res. J., April-June 2014, 3(2): 04-18}

survey completed one questionnaire. The questionnaire was compiled in three sections. The first section dealt with geographical and climatic aspects of the major citrus production areas. The second section covered the history of each citrus orchard, including farm size, rootstock and scion source, cultivars planted, orchard and/or tree age, ownership, flora composition around the orchard, soil type and application of fertilizer. The third section comprised the major diseases and insect pests, and the management practices used in each citrus orchard. Information collected from the different citrus orchards were combined for each question and summarized for the main parameters to give an overview of citrus production and field management practices in the country.

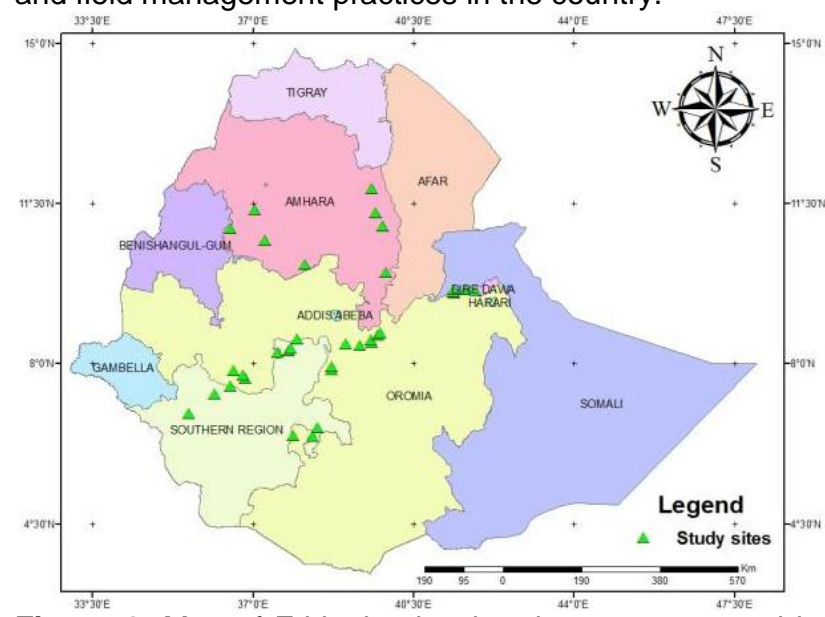

Figure 1: Map of Ethiopia showing the areas covered in surveys carried out in 2012 and 2013 to assess the occurrence and spread of Pseudocercospora leaf and fruit spot disease of citrus.

\section{Incidence and Severity of PLFS Disease of Citrus in Ethiopia}

Sampling was done in the forty-nine citrus orchards to map the distribution of PLFS disease in the country. The prevalence, incidence and severity of the disease were assessed based on the characteristic disease symptoms that were visually determined in the field on randomly selected citrus trees and plant parts. The geographic coordinates of the locations were taken using Global Positioning System (GPS 72H, Garmin Ltd., Taiwan) receiver to map the disease distribution.

Disease prevalence was determined by the number of sites surveyed showing PLFS disease symptoms, expressed as the percentage proportion of the total number of locations surveyed (Amata et al., 2009). Disease incidence and severity were determined by randomly taking five to ten representative citrus trees diagonally across the field in each orchard surveyed (Seif and Hillocks, 1999; Mohammed, 2007). The incidence and severity of each selected tree were determined and the mean of each site was calculated. Disease incidence on the foliage was estimated by counting visibly infected and total number of leaves on eight randomly selected terminal shoots from the upper and lower halves of the canopy in the four quadrants of each selected tree, and expressed as a percentage. Incidence on fruits was similarly assessed using 5 to 40 randomly selected intact fruits per tree depending on availability. Incidence was calculated based on the presence or absence of visible disease symptoms on each fruit. Assessment of severity on the foliage and fruits was done on the same samples 
Asmare Dagnew et al.,

used for disease incidence. Severity on leaves was estimated using the percentage leaf area infected based on a one-to-five scoring scale where $1=$ no symptoms, 2 $=1-25 \%, 3=26-50 \%, 4=51-75 \%$ and $5=$ above $75 \%$ (Amadi, 2008; Ezeibekwe, 2011). A similar scoring system was used for fruit severity, where $1=$ healthy, $2=$ less than $5 \%, 3=5-20 \%, 4=21-50 \%$ and $5=$ above $50 \%$ of fruit surface affected (Seif and Hillocks, 1999).

\section{Isolation and Identification of the Causative Agent}

Infected leaf and fruit samples were taken from trees showing PLFS disease symptoms. Samples were placed in labeled transparent plastic bags, covered with brown paper bags, kept in cool ice box containers and then transported to the laboratory for isolation and identification of the causative agent. In the laboratory, the samples were washed in tap water and surface sterilized in $70 \%$ ethanol followed by $5 \%$ Clorox, each for one minute, and then rinsed three times with distilled and autoclaved water. Sterilized leaves or fruit peels were cut, and four to six leaf discs or peel pieces were placed on each Petri dish containing potato dextrose agar (PDA) in five replicates and incubated at $25 \pm 1^{\circ} \mathrm{C}$. After five days of incubation, cultures were examined for the development of the causative agent. Cultures were purified using hyphal tipping onto fresh PDA medium and were incubated for four to seven days at $25 \pm 1^{\circ} \mathrm{C}$. The causative agent was characterized based on its phenotypic characteristics by visual observation and using a stereomicroscope.

Pathogenicity tests were conducted on apparently healthy, young leaves taken from actively growing citrus seedlings. Leaves were washed in distilled water and surface sterilized in $5 \%$ Clorox. They were rinsed repeatedly with sterile distilled water. Two sterilized leaves were placed, by keeping the abaxial side up, in each Petri dish containing water agar $(1 \%)$. Inoculation of leaves was carried out by placing drops of conidial suspension, with concentration of $10^{5}$ to $10^{6}$ conidia $\mathrm{mL}^{-1}$ (Eshetu, 1999; Seif and Hillocks, 1999). The Petri dishes were sealed with parafilm to maintain high relative humidity. Control leaves were inoculated with sterile distilled water. Cultures were incubated at $26^{\circ} \mathrm{C}$ for two weeks, and inoculated leaf samples were examined daily for disease symptom development. The re-isolation procedure was carried out from experimentally infected samples to demonstrate Koch's postulate. The re-isolated cultures were examined for cultural and morphological comparisons with the original cultures to confirm that it was indeed the same pathogen we had seen in the original culture.

For further genetic study, the fungal cultures were stored at $5^{\circ} \mathrm{C}$ in test tubes with slant PDA medium at the Biotechnology Laboratory of the Holetta Agricultural Research Center, Ethiopia.

\section{RESULTS AND DISCUSSION}

\section{Assessment of Citrus Orchards in Ethiopia}

To give an overview of the citrus production status and the field management practices used in the different citrus orchards in the country, categories of the general information and the representative answers given by the respondents of each citrus orchard considered, and the field observations made during the surveys are described in this section.
Sci. Technol. Arts Res. J., April-June 2014, 3(2): 04-18

\section{Geographical Locations and Climatic Conditions}

The areas covered in the surveys lie between $6.417^{\circ}$ and $11.831^{\circ}$ North latitude respectively at Guangua town (Dilla area) in the south and at Woldiya town in the northern part, and $35.593^{\circ}$ and $41.862^{\circ}$ East longitude at Bebeka in the southwest and at Dire Dawa in the eastern Ethiopia, respectively (Figure 1). The locations surveyed have altitudes ranging from 900 meters above sea level (m.a.s.l) at Bebeka to $2000 \mathrm{~m}$ in Agaro area, with a wide range of soil types (Table 1 ).

According to the climatic information obtained from the orchards surveyed (Table 1), the mean minimum temperatures ranged from $10^{\circ} \mathrm{C}$ at Nura Era in the central rift valley to $21^{\circ} \mathrm{C}$ at Lado around Lake Abaya in the south. Similarly, the mean maximum temperatures varied from $21^{\circ} \mathrm{C}$ at Bikolo in the northwest to $37.5^{\circ} \mathrm{C}$ at Nura Era. The optimum temperature to induce flowering in citrus is between $13^{\circ} \mathrm{C}$ and $24^{\circ} \mathrm{C}$ with a tolerance range of $\pm 3^{\circ} \mathrm{C}$ (Davies and Albrigo, 1994). The results showed that almost all citrus orchards surveyed have temperature ranges which are ideal for citrus production. The mean annual rainfalls for the areas surveyed ranged from 316 $\mathrm{mm}$ at Nura Era to $1750 \mathrm{~mm}$ at Bebeka. The major citrus producing areas have long growing seasons with low precipitation, but most of them are with river, lake or ground water supply. However, the period of the rainy season and the precipitation intensity and distribution vary from area to area. The mean annual rainfalls of the main citrus producing areas were between $316 \mathrm{~mm}$ and 500 $\mathrm{mm}$ (Table 1), which necessitates the application of supplementary irrigation water. However, long, wet rainy seasons were reported to favor the development of high disease pressure and increase preharvest fruit loss of citrus (Seifu, 2003; Sisay, 2007).

\section{Citrus Production in Ethiopia}

Citrus farming in Ethiopia is a mixed agriculture (Seifu, 2003; Sisay, 2007), in which, many horticultural, field and forage crops, and shade trees are grown with and around citrus plantings. According to the information obtained from the surveys, several fruit crops (mainly mango, banana, avocado and papaya), vegetable crops (primarily tomato and onion), coffee, and maize were the major ones integrated in most of the citrus plantings and/or grown around citrus orchards. The orchards considered in the surveys represented plantings with ages ranging from 2 to 70 years old. About $60 \%$ of the citrus orchards surveyed constituted younger plantings, 20 and less years of age while the rest $40 \%$ of the orchards had plantings of over 20 years old.

\section{Area Coverage and Ownership of the Orchards}

The land holdings of citrus orchards surveyed varied from 0.15 ha by the smallholder farmers to 10,030 ha for Bebeka Coffee Estate farm. The area coverage of citrus plantation for these orchards ranged from a few citrus trees in the backyards of smallholders to 1,000 ha at Nura Era citrus farm. About $83.7 \%$ of the orchards surveyed had citrus plantings of 10 ha or less, and $12.2 \%$ of the orchards were with citrus plantings between 10 and 100 ha. Only a few citrus orchards had area coverage greater than 100 ha.

The ownership of the citrus orchards considered in the survey was also assessed. Nearly half of the orchards (24 out of 49) were owned by smallholder farmers. Eighteen orchards were state-owned (some of them were in the 
Table 1: Description of the geographic locations and climatic conditions of citrus orchards surveyed in 2012 and 2013 in Ethiopia

\begin{tabular}{|c|c|c|c|c|c|}
\hline Citrus Orchards & $\begin{array}{l}\text { Altitude } \\
\text { (m.a.s.l) }\end{array}$ & $\begin{array}{c}\text { Mean } \\
\text { temperature } \\
\text { range }\left({ }^{\circ} \mathrm{C}\right)\end{array}$ & $\begin{array}{l}\text { Mean annual } \\
\text { rainfall } \\
(\mathrm{mm})\end{array}$ & $\begin{array}{c}\text { Relative } \\
\text { humidity } \\
(\%)\end{array}$ & Soil type \\
\hline \multicolumn{6}{|l|}{ MIDROC, Horizon Plantation S.C. } \\
\hline Bebeka Coffee Estate & $900-1200$ & $15-30$ & 1750 & No data & Vertisol \\
\hline Nura Era & $1100-1205$ & $10-37.5$ & 316 & 44.3 & Clay to sandy loam \\
\hline \multicolumn{6}{|l|}{ Upper Awash Agro Industry Enterprise } \\
\hline Merti & 1100 & $11-34$ & 383 & No data & Black soil \\
\hline Abadeshka-Jeju & 1100 & $11-34$ & 383 & No data & Black soil \\
\hline \multicolumn{6}{|l|}{ Erer Gota Citrus Farms } \\
\hline Erer & 1120 & $18-27$ & $425-500$ & No data & Sandy loam \\
\hline Fetuli & 1180 & $18-27$ & $425-500$ & No data & Sandy loam \\
\hline Gota & 1120 & $18-26$ & $425-500$ & No data & Sandy loam \\
\hline Hurso & 1130 & No data & No data & No data & Sandy loam \\
\hline \multicolumn{6}{|c|}{ Federal Prison Administration Citrus Farms } \\
\hline Ziway & 1680 & $13-28$ & 600 & 52 & Sandy loam \\
\hline Shewarobit & 1320 & $16-30$ & 425 & 44.5 & Black heavy soil \\
\hline Tibila, AfricaJuice Tibila S.C. & 1240 & $16-36$ & 700 & No data & Clay loam \\
\hline Gibe, Ethiopian Seed Enterprise & 1100 & $15-35$ & 800 & No data & Vertisol \\
\hline \multicolumn{6}{|l|}{ Government Fruit Nurseries } \\
\hline Guangua (Dilla area) & $1620-1680$ & $18-24$ & 1000 & No data & Sandy soil \\
\hline Bikolo & 1900 & $12-21$ & 828 & No data & Brown soil \\
\hline Chagni & 1750 & $15-28$ & No data & No data & Red to brown soil \\
\hline Finote Selam & 1800 & $14-26$ & No data & No data & Red soil \\
\hline Dejen (Kurar) & 1600 & No data & No data & No data & No data \\
\hline Harbu & 1560 & No data & No data & No data & Black soil \\
\hline \multicolumn{6}{|l|}{ Research Foundation Blocks } \\
\hline Melkassa Agricultural Research Center & 1550 & $13-28$ & 750 & 77 & Sandy loam \\
\hline Jarre, Hayk Research Sub-Center & 1700 & $14-28$ & 500 & No data & Clay loam \\
\hline Jimma University & 1780 & $14-30$ & 1150 & No data & Red soil \\
\hline Tony Farm, Haramaya University & 1280 & $18-28$ & 595 & 42.2 & Sandy loam \\
\hline \multicolumn{6}{|l|}{ Citrus Farms of Private Investors } \\
\hline Ethioflora & 1600 & $13-28$ & 543 & 52 & Sandy soil \\
\hline Woldiya & 1760 & No data & 800 & No data & Brown soil \\
\hline Koka & 1595 & No data & No data & No data & Sandy loam \\
\hline \multicolumn{6}{|l|}{ Orchards of Smallholders } \\
\hline Aleta Wendo & 1900 & $12-26$ & 1400 & No data & Red soil \\
\hline Abeshege (Welkite) & $1830-1860$ & $10.3-25.9$ & 1244 & No data & Red to brown soil \\
\hline Kebena & 1780 & $10-26$ & 1240 & No data & Vertisol \\
\hline Ginbo & $1440-1500$ & No data & No data & No data & Red brown sandy loam \\
\hline Lado (Lake Abaya) & 1280 & $21-32$ & 900 & No data & Clay black soil \\
\hline Senbo & 1440 & No data & No data & No data & Black soil \\
\hline Agaro & $1680-2000$ & No data & No data & No data & Red to Brown soil \\
\hline Yebu & $1620-1640$ & $11.6-27.1$ & 1640 & No data & Red soil \\
\hline Goro (Woliso) & 1860 & No data & 1260 & No data & Black soil \\
\hline $\begin{array}{l}\text { Association, Harbu Tropical Fruits } \\
\text { Propagator Farmers }\end{array}$ & 1600 & No data & No data & No data & Black soil \\
\hline
\end{tabular}

process of privatization), while six orchards were owned by private companies. One orchard was owned by Farmers' Association. However, in terms of area coverage, the ownerships of the private companies, the government and Farmers' Association represented $1115.1,503.52$ and 8.5 ha, respectively. The smallholder farmers in total contributed only 1.0 ha of citrus plantings because they grow a few or several citrus trees in their backyards.

\section{Citrus Species and Varieties}

Different citrus species and varieties are cultivated in the country. The information obtained from the surveys showed that sweet orange, mandarin, lime, lemon, grapefruit, citrus hybrids, sour orange and citron were produced in $48,18,15,13,5,3,3$ and 2 of the 49 orchards surveyed, respectively (data not shown). The most dominant sweet orange variety produced in the country was Valencia (in $61.1 \%$ of the locations considered) followed by unknown variety (58.3\%), Washington Naval (47.2\%), Hamlin (44.4\%), Pineapple $(38.9 \%)$, and Jaffa (16.7\%). Algerian Tangerine (in 36.1\% of the locations), Fairchild (30.6\%) and Dancy (27.8\%) were the most widely produced mandarin varieties. Among limes and lemons, UCR Meyer (in 25\% of the locations), Bears (22.2\%), Allen Eureka (13.9\%) and Mexican Lime (11.1\%) varieties were produced. Citrus hybrids, grapefruit and citron varieties were the least produced.

Citrus trees that were grown by smallholder farmers were directly from seeds and were not grafted. However, 
Asmare Dagnew et al.,

citrus trees in state and private owned orchards, government nurseries and research foundation blocks were grafted. The original sources of scions and rootstocks of most old orchards were unknown, but $33.3 \%$ of the respondents did not have available information. The lack of information in this regard could complicate management and breeding programs aimed at improving citrus production (Sisay, 2007). However, the major sources of the recent citrus plantations included University of California at Riverside, Melka Sedi Farm in the Middle Awash, Upper Awash Agro Industry Enterprise, Research Centers, ICRISAT, and local growers. The most commonly used rootstocks were Sour orange, Volkameriana and Troyer Citrange.

\section{Irrigation and Fertilization Practices}

Moisture is a limiting factor for good quality citrus production. The mean annual rainfalls reported for the major citrus orchards during the surveys were below 500 $\mathrm{mm}$ (Table 1). These citrus orchards (24 out of 49) used the nearby rivers or lakes for irrigation purposes. The frequency of irrigation water application in most of these orchards averaged once or twice a month using the traditional double ring basin method of irrigation (Seifu, 2003; Sisay, 2007). Application of surface water at wider intervals creates moisture stress during early spring while the tree is at flowering stage. This could result in excessive drop of flowers and immature fruits, followed by smaller crop yield. Drought followed by good rains could also lead to out-of season flowering and fruit setting. Saturated and poorly drained citrus orchard soils can contribute to root rot and tree dieback, which may ultimately result in total yield loss (Sisay, 2007). The improper use of the irrigation system can create a direct contact between tree bark and surface water, which results in increased soil borne disease infections and eventually tree dieback (Caruso and Wilcox, 1990; Oudemans, 1999).

According to the information obtained from the respondents, fertilizer application was not practiced in most of the citrus orchards, particularly those orchards owned by small-scale farmers $(71.4 \%$, or 35 out of 49$)$. The big citrus producing orchards $(18.4 \%$, or 9$)$ reported applying DAP and Urea chemical fertilizers to their citrus trees. The use of both chemical fertilizers and animal manure was reported by Ethioflora, Melkassa and Hurso citrus orchards. Application of animal manure and compost to fertilize citrus trees was reported by Woldiya and Bikolo citrus orchards, respectively. However, fertilizer application in all citrus orchards in the country was not based on soil and plant tissue nutrient analyses.

\section{Preharvest Diseases and Disorders of Citrus}

Many of the respondents differentiated between citrus insect pests and diseases during production. However, they have difficulties to identify diseases incited by pathogens from abiotic disorders. According to the information obtained from the respondents and field observations made during the surveys, most citrus orchards had suffered from complex of diseases (Table 2). Virus and virus-like diseases including tristeza, greening and exocortis, and unknown diseases were reported to cause tree decline and dieback at Erer Gota, Hurso, Tony, Nura Era, Merti, Melkassa, Koka, Ziway, Ethioflora, Shewarobit, Harbu, Gibe, Ginbo, and Bebeka citrus orchards. In these orchards, symptoms of leaf

\section{Sci. Technol. Arts Res. J., April-June 2014, 3(2): 04-18}

yellowing, mottling and cupping, dying of twigs, stunting, and deterioration of trees were clearly observed.

Citrus trees at Fetuli, Hurso, Tony, Nura Era, Merti, Abadeshka-Jeju, Melkassa, Ethioflora, Shewarobit and Gibe orchards were attacked by several diseases caused by plant pathogens such as Phytophthora (primarily on sweet oranges and mandarins), citrus anthracnose (on mandarins) and bacterial canker (on acid limes). During the survey, field symptoms of PLFS disease were observed in twenty-eight citrus orchards $(57.14 \%)$ in the south, southwest, northwest and central north parts of the country. Symptoms of lichens (fungus and algae that grow together) on leaves and stems of most citrus trees at Bebeka and Ginbo, melanose at Gibe and Lado, sooty mold at Melkassa and Lado, and fruit rots at Melkassa and Tony citrus orchards were recorded during the survey. The problem of nematodes was seen only at Tony farm.

Deformation and scion-rootstock incompatibility were observed at Ethioflora and Dejen (Kurar) citrus orchards. Although there were no soil and tissue analyses, salinity problem was suspected at Ziway orchard. Nutrient imbalance symptoms, mainly deficiency of trace elements were observed in many of the orchards surveyed (65.3\%), especially in farms owned by smallholder farmers and by the state (Table 2). At Chagni, nutrient imbalance symptoms were observed on all citrus trees regardless of the species. Serious moisture stress which has caused leaf wilting, fruit cracking and premature fruit drop was also observed in Gota, Nura Era, Abadeshka-Jeju, Jarre, Kurar and Goro citrus orchards.

In Ethiopia, citrus trees have been afflicted due to different diseases incited by many fungi, bacteria, viruses and virus-like organisms. Viruses and virus-like diseases including psorosis, tristeza and greening were reported to be of great economic importance and thought to play a significant role in the decline of citrus plantation in the country (Tesfaye and Habtu, 1985; Lemma, 1994; Mohammed and Getachew, 1995). Citrus canker, caused by a bacterium, is a serious disease of most commercial citrus cultivars and some citrus relatives (Schubert and Miller, 2000). Eshetu and Sijam (2007) reported the occurrence of citrus canker disease on Mexican lime and sour orange in some citrus orchards in Ethiopia. Various fungal pathogens including Phytophtora, Penicillium, Colletotrichum and Phaeoramularia species seriously affected citrus trees in Ethiopia (Eshetu, 1999; Yigzaw and Gelelbelu, 2002; Seifu, 2003; Mohammed, 2007; Sisay, 2007). Based on field observations citrus producers had reported $13.6 \%$ of citrus trees dieback due to virus problems and over $35 \%$ citrus attack by other plant pathogens in the major citrus farms across Ethiopia (Sisay, 2007).

Phytophthora species cause the most serious problem and are economically important soil-borne diseases of citrus (Graham and Timmer, 1994). Previous reports in Ethiopia indicated high severity of soil-borne diseases caused by Phytophthora species in many citrus orchards (Seifu, 2003; Sisay, 2007). Intrinsic factors such as lack of certified planting material, inappropriate use of cultural practices, and adverse edaphic conditions may increase the rate of infection and the spread of the disease in an orchard (Salerno and Cutuli, 1982). The use of inappropriate irrigation system can result in increased 
Asmare Dagnew et al.,

Phytophthora infection and ultimately tree dieback (Caruso and Wilcox, 1990; Oudemans, 1999). Poor rootstock-scion combinations were also attributed to high levels of gummosis and Phytophthora root rot (Ippolito et al., 1996). Therefore, the proper use of irrigation methods and selection of disease resistant rootstocks can reduce the risk of infection by soil borne pathogens (Salerno and Cutuli, 1982).

The knowledge and scientific identification of diseases and disorders is very limited in Ethiopia. The use of robust and fast diagnostic techniques for accurate identification is therefore crucial for the development of more effective disease management strategies and to improve the current production practices in the country (Sisay, 2007).

\section{Insect Pests of Citrus}

Insect pests on citrus were found to be equally important to diseases. Based on the information obtained from the respondents and field observations made during the surveys, leafminer $(77.6 \%)$, red scales $(57.1 \%)$, citrus thrips (24.5\%), cottony cushion scales (16.3\%), Mediterranean fruit fly $(14.3 \%)$, and woolly whitefly $(10.2 \%)$ were reported as the major insect pests on citrus in the orchards surveyed (Table 2). Attacks by false codling moth, mealy bug, bud mite, orange dog and termites were reported from several citrus orchards. Red scale infestation at Tibila citrus farm was extremely severe; it attacked leaves and fruits, made the twigs dry and led the trees deteriorate. Both red scale and leafminer were the most serious pests attacking citrus trees at Melkassa orchard. At Nura Era, woolly white fly was found the most important pest on citrus trees. Similarly, Sisay (2007) reported more than $50 \%$ preharvest fruit damage due to these insect pests of in Ethiopia.

Citrus production in Ethiopia is severely threatened by numerous insect pests. In the past few decades, a large number of insect pests have been identified and documented. Accordingly, the major insect pests of citrus in the country included scales, woolly white fly, Mediterranean fruit fly, false codling moth, citrus thrips, leafminer and fruit flies (Emana et al., 2003; Ferdu et al., 2009). The results of the existing surveys were also consistent with these previous reports.

The start of insect attack and extent of damage in citrus orchards was found to vary depending on tree age and fruit maturity. In the current study, many respondents indicated very high leafminer infestation on leaves of young plants and on newly emerging leaves of older citrus trees. Respondents also reported initial infestation of scale insects and Mediterranean fruit fly attacks during fruit development and ripening stages. In citrus cultivation, regular monitoring of orchard practices from land preparation to fruit maturity and harvesting can provide sufficient information to control infestations of citrus trees (Taylor, 1997).

\section{Management of Preharvest Diseases and Insect Pests of Citrus}

Citrus trees in most of the orchards, especially those owned by smallholder farmers, were not well-managed. The citrus orchard at Bebeka had been neglected for the past several years due to PLFS disease. The disease severely affected the trees. In some other orchards like Guangua weed infestation was very serious. Survey
Sci. Technol. Arts Res. J., April-June 2014, 3(2): 04-18

results showed that no control measures except sanitation in some orchards were practiced against PLFS disease. Citrus orchards at Bikolo, Chagni, Finote Selam, Nura Era and Merti did practice back pruning of dried twigs and branches to rejuvenate new branches. At Erer Gota, the second largest citrus farm next to Nura Era in area coverage, pruning of dead branches and uprooting of dead trees were also practiced. Most medium and large scale citrus plantations were sprayed with pesticides. According to the information obtained from the respondents, some government nurseries such as Bikolo, Chagni and Finote Selam stopped to propagate and distribute citrus planting materials due to PLFS disease.

About $43 \%$ of the citrus orchards surveyed apply pesticides as a major means of disease and/or insect pest control (Table 2). The remaining orchards, especially those owned by the smallholder farmers, do not use pesticides. Kocide 101, Mancozeb, Bayleton, Ridomil MZ, Ridomil 5G, and Daconil fungicides, as well as Diazinon, Karate, Selecron, Suprathion, Endosulfan, Ultracide, Confider, White mineral oil, Diazol, Thiodan, Sumithion, Dimethoate and Methidathion insecticides were applied to control diseases and insect pests in the orchards surveyed. Of these pesticides, Kocide 101, Mancozeb and Bayleton fungicides, and Diazinon and Karate insecticides were the most widely applied pesticides for citrus disease and insect pest control, respectively.

The application of pesticides only during the first observation of the pest may lead to ineffective control and can result in buildup of the inoculum over time and eventually disease outbreak in an area (Fry, 1977). It is required to investigate into alternative natural plant products (Tripathi and Dubey, 2004), microbial antagonists (Droby et al., 1991) and the application of improved sanitary practices (Sierra et al., 1993; Wilson et al., 1995) in order to reduce the risks associated with ineffective application of chemicals and its environmental and health considerations. In Ethiopia, various experiments have been conducted and different pest control methods including cultural practices, bait sprays and attractants, a number of insecticides, parasitoids and predators, and botanicals were recommended for the management and control of major insect pests (Tsedeke 1983, 1991; Ferdu et al. 2009). However, most citrus growers in the country do not apply recommended pesticide at a recommended rate and frequency.

\section{Pseudocercospora Leaf and Fruit Spot Disease of Citrus in Ethiopia \\ Prevalence and Distribution}

The results of the field surveys indicated the current occurrence and spread of PLFS disease in Ethiopia (Figure 2). The disease was widely spread in the south, southwest, northwest and central north parts of the country. The disease was found prevalent in $63.2 \%$ of the citrus orchards surveyed in the major citrus growing administrative zones of the country (Table 3 ). In south Wello zone, field symptoms of leaf and fruit spot disease were observed only at Jarre. Based on visual observations, no symptoms of PLFS disease were recorded in citrus orchards found in east Gojjam, north Shewa, north Wello, east Shewa, Shinile and Dire Dawa zones. In Jimma zone, the disease was locally known as 'Cholera' due to the devastating nature of the disease. 
Table 2: Diseases and insect pests recorded, and use of pesticides in citrus orchards surveyed in 2012 and 2013.

\begin{tabular}{|c|c|c|c|}
\hline Citrus Orchards & $\begin{array}{c}\text { Diseases and/or Disorders } \\
\text { Observed Based on Field } \\
\text { Symptoms }\end{array}$ & Major Insect Pests Recorded & $\begin{array}{l}\text { Chemical Pesticides } \\
\text { Use }\end{array}$ \\
\hline Bebeka & $\begin{array}{l}\text { PLFS, Lichens, Nutrient } \\
\text { imbalance, decline }\end{array}$ & Leafminer, Red scale & No application \\
\hline Nura Era & $\begin{array}{l}\text { Citrus Canker; Sudden death/ } \\
\text { Tristeza, Phytophthora rot, } \\
\text { Dieback, Nutrient imbalance, } \\
\text { Water stress }\end{array}$ & $\begin{array}{l}\text { Woolly white fly ("Sukarie"), Med } \\
\text { fruit fly, Leafminer, Red scale, } \\
\text { Citrus thrips, Cottony cushion } \\
\text { scale, Termite }\end{array}$ & $\begin{array}{l}\text { Ultracide, Diazinon, } \\
\text { Diazol, White mineral oil }\end{array}$ \\
\hline Merti & $\begin{array}{l}\text { Anthracnose, Dieback, Nutrient } \\
\text { imbalance }\end{array}$ & $\begin{array}{l}\text { Leafminer, Cottony cushion } \\
\text { scale }\end{array}$ & $\begin{array}{l}\text { Ultracide, Diazinon, } \\
\text { Diazol, White mineral oil }\end{array}$ \\
\hline Abadeshka-Jeju & $\begin{array}{l}\text { Anthracnose, Nutrient imbalance, } \\
\text { Water stress }\end{array}$ & $\begin{array}{l}\text { Leafminer, Woolly white fly, } \\
\text { Red scale, Citrus thrips }\end{array}$ & Same as in Merti \\
\hline Erer & $\begin{array}{l}\text { Tristeza, Greening, Nutrient } \\
\text { imbalance, Unknown disease }\end{array}$ & Leafminer, Citrus thrips & $\begin{array}{l}\text { Kocide 101, Ridomil MZ, } \\
\text { Ridomil 5G, Bayleton, } \\
\text { Mancozeb; Selecron, } \\
\text { Suprathion, Endosulfan, } \\
\text { Karate, Diazinon }\end{array}$ \\
\hline Fetuli & $\begin{array}{l}\text { Tristeza, Exocortis viroid, } \\
\text { Phytophthora }\end{array}$ & Leafminer & Same as in Erer \\
\hline Gota & $\begin{array}{l}\text { Tristeza, Exocortis viroid, Nutrient } \\
\text { imbalance, Water stress }\end{array}$ & Leafminer, Citrus thrips & Same as in Erer \\
\hline Hurso & $\begin{array}{l}\text { Phytophthora, Tristeza, Greening, } \\
\text { Nutritional imbalance }\end{array}$ & $\begin{array}{l}\text { Red scale, Leafminer, Citrus } \\
\text { thrips, Bud mite }\end{array}$ & $\begin{array}{l}\text { Mancozeb, Diazinon, } \\
\text { Methidathion, Sumithion }\end{array}$ \\
\hline Ziway & $\begin{array}{l}\text { Decline/Dieback, Nutrient } \\
\text { imbalance, Salinity }\end{array}$ & $\begin{array}{l}\text { Cottony cushion scale, Leaf } \\
\text { miner, Citrus thrips, Med fruit fly }\end{array}$ & Karate \\
\hline Shewarobit & $\begin{array}{l}\text { Greening, Dieback, Phytophthora } \\
\text { disease }\end{array}$ & Red scale & Mancozeb, Bayleton \\
\hline Tibila (Tifhste Genet) & Nutrient imbalance & $\begin{array}{l}\text { Red scale, Woolly white fly, Fruit } \\
\text { fly, False codling moth, } \\
\text { Leafminer, Thrips, Mealy bug, } \\
\text { Cottony cushion scale }\end{array}$ & Diazinon, Confider \\
\hline Gibe & $\begin{array}{l}\text { PLFS, Canker, Dieback, } \\
\text { Gummosis, Tristeza, Greening, } \\
\text { Melanose, Nutrient imbalance }\end{array}$ & $\begin{array}{l}\text { Leafminer, Scales (red and } \\
\text { black), Citrus thrips, Orange } \\
\text { dog, Med fruit fly }\end{array}$ & Ultracide, Karate \\
\hline Guangua (Dilla area) & PLFS, Nutrient imbalance & Leafminer & No application \\
\hline Bikolo & PLFS, Nutrient imbalance & Red scale & Kocide \\
\hline Chagni & PLFS, Nutrient imbalance & Leafminer & Daconil, Kocide \\
\hline Finote Selam & PLFS & $\begin{array}{l}\text { Leafminer, Red scale, } \\
\text { Cottony cushion scale }\end{array}$ & Bayleton \\
\hline Dejen (Kurar) & $\begin{array}{l}\text { Deformation on graft union, Fruit } \\
\text { drop, Water stress }\end{array}$ & Red scale & No application \\
\hline Harbu (South Wello) & Dieback & Woolly white fly & No application \\
\hline Melkassa & $\begin{array}{l}\text { Dieback, Tristeza, Greening, } \\
\text { Citrus Canker, Anthracnose, Fruit } \\
\text { rot, Sooty mold, Nutrient imbalance }\end{array}$ & $\begin{array}{l}\text { Red scale, Leafminer, } \\
\text { Cottony cushion scale, } \\
\text { Citrus thrips, Med fruit fly }\end{array}$ & $\begin{array}{l}\text { Dimethoate, Karate, } \\
\text { Diazinon } 60\end{array}$ \\
\hline Jarre (Hayk) & Leaf and fruit spot, Water stress & Leafminer, Red scale & No application \\
\hline Jimma City & PLFS, Nutrient imbalance & Leafminer, Red scale & No application \\
\hline Tony Farm (Dire Dawa) & $\begin{array}{l}\text { Tristeza, Exocortis viroid, Greening } \\
\text { Phytophthora/ Nematodes, Fruit } \\
\text { rot, Nutritional imbalance }\end{array}$ & $\begin{array}{l}\text { Termite, Med fruit fly, } \\
\text { Leafminer, } \\
\text { Red scale }\end{array}$ & Methidathion, Sumithion \\
\hline Ethioflora (Adami Tulu) & $\begin{array}{l}\text { Phytophthora, Gummosis, Graft } \\
\text { incompatibility, Nutrient imbalance }\end{array}$ & Leafminer, Med fruit fly & Diazinon, Thiodan \\
\hline Woldiya & No disease & Red scale & No data \\
\hline Koka & Decline, Nutrient imbalance & Leafminer & No data \\
\hline Aleta Wendo & PLFS, Nutrient imbalance & Leafminer & No application \\
\hline Abeshege (Welkite area) & PLFS, Nutrient imbalance & Leafminer, Red scale & Daconil, Kocide \\
\hline Kebena & PLFS, Nutrient imbalance & Leafminer & No application \\
\hline Ginbo & PLFS, Lichens, Greening & Leafminer, Red scale & No application \\
\hline Lado (Lake Abaya area) & $\begin{array}{l}\text { PLFS, Sooty mold, Melanose, } \\
\text { Nutrient imbalance }\end{array}$ & $\begin{array}{l}\text { Leafminer, Red scale, Citrus } \\
\text { thrips }\end{array}$ & No application \\
\hline Senbo & PLFS, Nutrient imbalance & $\begin{array}{l}\text { Red scale, Leafminer, } \\
\text { Cottony cushion scale }\end{array}$ & No application \\
\hline Agaro & PLFS, Nutrient imbalance & Leafminer, Red scales & No application \\
\hline Yebu & PLFS, Nutrient imbalance & Leafminer, Red scales & No application \\
\hline Goro (Woliso area) & PLFS, Nutrient imbalance & Leafminer & No application \\
\hline $\begin{array}{l}\text { Harbu Tropical Fruits } \\
\text { Propagator Farmers } \\
\text { Association }\end{array}$ & Dieback & Woolly white fly, Leafminer & No data \\
\hline
\end{tabular}




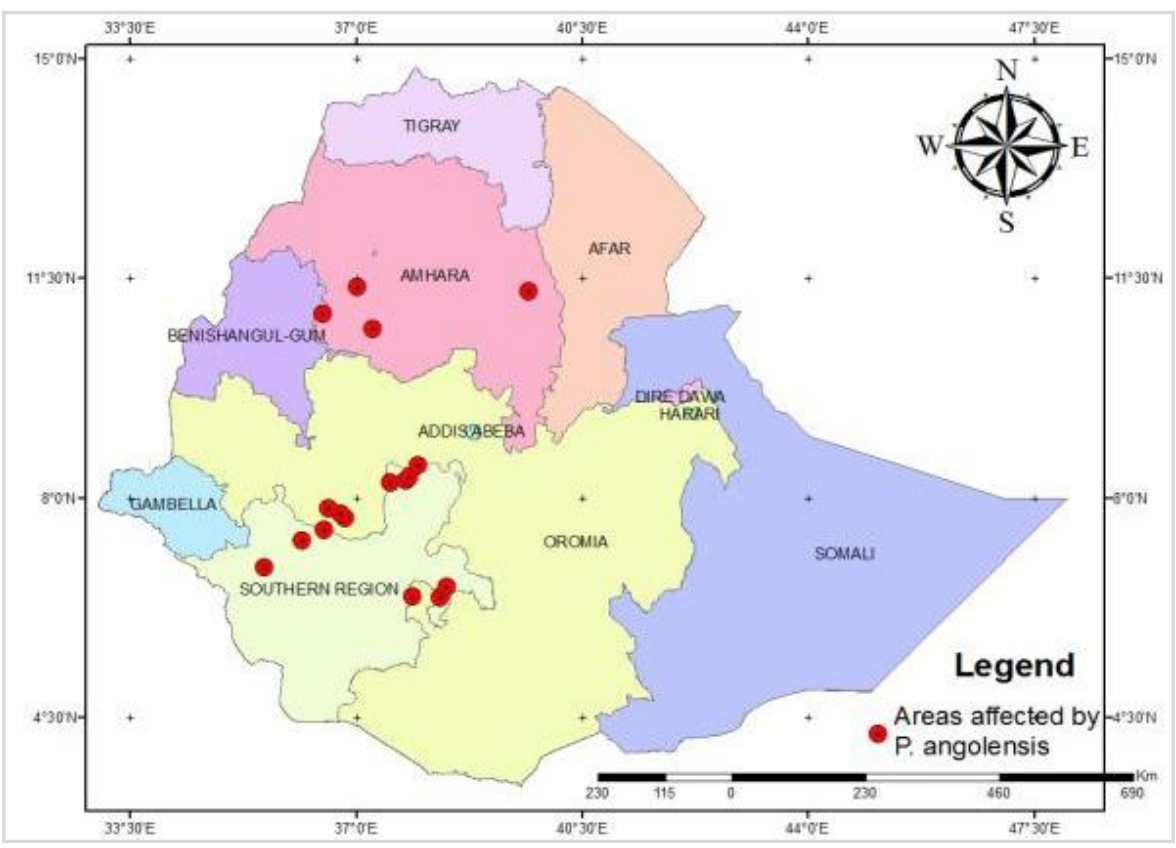

Figure 2: Distribution of Pseudocercospora leaf and fruit spot of citrus in Ethiopia

Table 3: Prevalence of Pseudocercospora leaf and fruit spot disease of citrus observed in the main citrus growing administrative zones of Ethiopia in the 2012 and 2013 surveys

\begin{tabular}{clccc}
\hline $\begin{array}{c}\text { Regional } \\
\text { States }\end{array}$ & \multicolumn{1}{c}{ Zones } & $\begin{array}{c}\text { Citrus orchards } \\
\text { evaluated }\end{array}$ & $\begin{array}{c}\text { Infected } \\
\text { orchards }\end{array}$ & $\begin{array}{c}\text { Prevalence } \\
(\%)\end{array}$ \\
\hline \multirow{5}{*}{ Amhara } & Awi & 3 & 3 & 100 \\
& West Gojjam & 5 & 5 & 100 \\
& South Wello & 4 & 1 & 25 \\
& East Gojjam & 3 & 0 & 0 \\
& North Shewa & 3 & 0 & 0 \\
& North Wello & 3 & 0 & 0 \\
\hline \multirow{5}{*}{ Oromia } & Borena & 4 & 4 & 100 \\
& Jimma City & 3 & 3 & 100 \\
& Jimma & 10 & 10 & 100 \\
& Southwest Shewa & 3 & 3 & 100 \\
& East Shewa & 8 & 0 & 0 \\
\hline \multirow{5}{*}{ SNNP } & Bench-Maji & 3 & 3 & 100 \\
& Gurage & 5 & 5 & 100 \\
& Kaffa & 4 & 4 & 100 \\
& Sidama & 2 & 2 & 100 \\
\hline Somali & Shinile & 4 & 0 & 0 \\
\hline Dire Dawa & Dire Dawa City & 1 & 0 & 0 \\
\hline & SNNP = South Nations, Nationalities and People &
\end{tabular}

\section{PLFS Disease Incidence and Severity Assessment of Field Symptoms}

The PLFS disease affects the different parts of the plant. In the orchards surveyed, the disease commonly affected leaves and fruits. In addition, symptoms were observed on twigs of sweet oranges and mandarins. During the surveys, citrus growers indicated that the disease begins infection on leaves and then progresses to fruits and twigs. In the field, the disease caused leaf spots, blemish fruits that remain on the tree, premature leaf and fruit drop, and drying of tips of twigs. The characteristic field symptoms of PLFS disease are indicated in Figure 3.

Field symptoms of the spot disease observed on leaves and some fruits of sweet orange at Jarre orchard (Figure 4a) in south Wello zone were somehow different from the symptoms in other orchards. Infected leaf samples were isolated in the laboratory and the causative agent was culturally and morphologically identified as similar to $P$. angolensis; but it needs further confirmation. Jarre is the only orchard in the central north part of the country where leaf and fruit spot-like disease symptoms were observed. Pretorius (2005) reported similar symptoms in Zimbabwe as concentric ring blotch on citrus leaves caused by grey mite. However, grey mites were not observed at Jarre during the surveys.

At Bebeka, spot-like symptoms that are similar to the PLFS disease were observed on a coffee shade tree (Figure $4 \mathrm{~b}$ and $4 \mathrm{c}$ ). Infected leaf samples were isolated in the laboratory and the causative agent was morphologically identified as similar to $P$. angolensis. However, it needs to be confirmed by molecular characterization of the pathogen, and clarified whether the coffee shade tree is an alternate host or the disease infects other plant species outside the genus Citrus. 

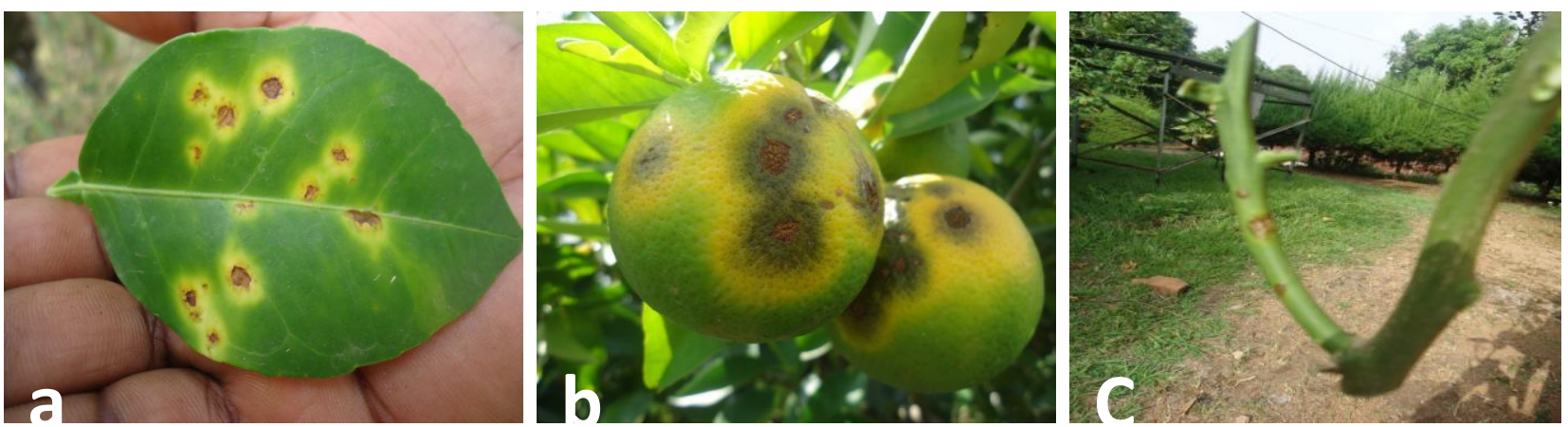

Figure 3: Symptoms of Pseudocercospora leaf and fruit spot: (a) chlorotic lesions on a leaf; (b) immature fruit with halo, gray colored symptoms on the surface and dead tissue at the center of the lesion; and (c) lesions on small, young branch.
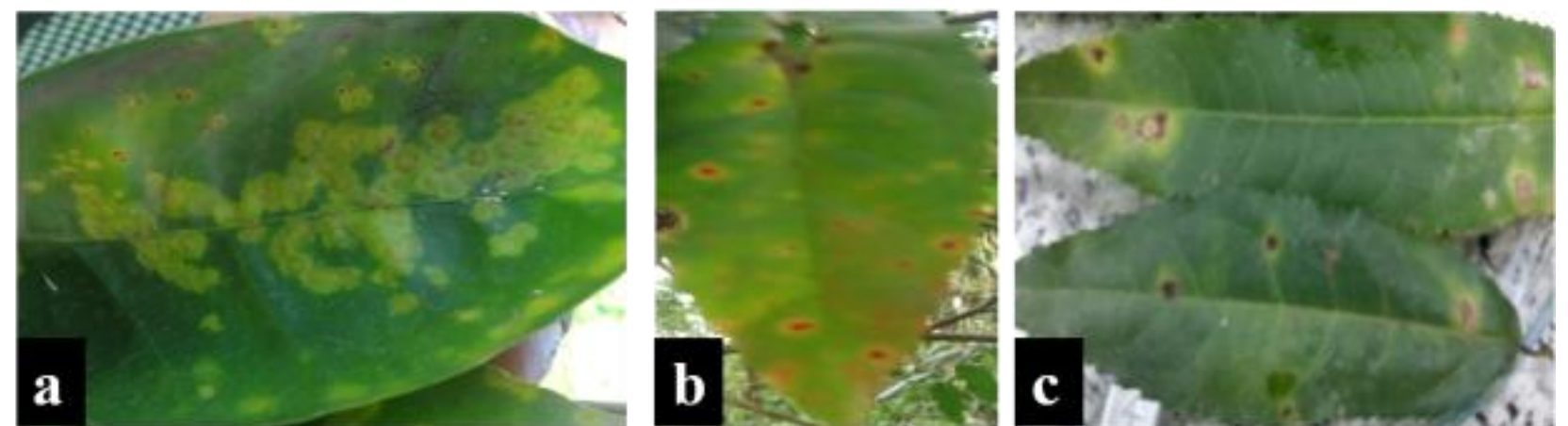

Figure 4: Leaf and fruit spot-like symptoms (a) on sweet orange leaf at Jarre orchard, south Wello, and (b, c) on leaves of a coffee shade tree at Bebeka orchard, Bench Maji zone.

\section{PLFS Disease Incidence and Severity in the Different Districts}

In the districts surveyed, the percentage of PLFS disease incidences on citrus in the various orchards ranged from zero to $100 \%$ while its severity ratings varied from one to five (Table 4). The highest mean incidence on leaves was $60.4 \%$ at Jimma City followed by $56.1,53.9$ and $50.2 \%$ in Aleta Wendo, Abeshege and Kebena, respectively. The maximum incidence $(100 \%)$ on fruits was recorded in Aleta Wendo. From 50 to $92 \%$ average disease incidences on fruits were recorded in Abeshege, Debre Werk, Mana, Kebena, Ginbo, Jimma City and Shebe Senbo. Similarly, the highest severity ratings on leaves (3.8) and fruits (5.0) were recorded in Aleta Wendo (Table 4). Above 2.5 ratings of disease severity on leaves were recorded in Abeshege, Debre Werk and Jabitehnan districts. Higher disease severity ratings on fruits that ranged from 4.0 to 4.6 were recorded in six districts. In Aleta Wendo and several citrus orchards of small-scale farmers in Abeshege and Mana districts, complete damage of fruits was observed. Disease incidence and severity were nil on citrus leaves and fruits in 12 and 13 districts, respectively (Table 4 ). In the past years, PLFS disease was reported in various areas in the south, southwest, and northwest Ethiopia (Eshetu, 1999; Yigzaw and Gelelbelu, 2002; Kassahun et al., 2006; Mohammed, 2007). The results of the present survey showed that the disease was spread to new areas in the northwest areas such as Bikolo and Bahir Dar, and the north central part like Jarre that were not reported to have the disease in the past. This was a clear indication for the need for continuous monitoring, and putting in place an internal quarantine system to avoid the spread of the disease in to new areas. Disease incidence and severity were higher in areas located in the south and southwest than those in the northwest and central north Ethiopia. This could be due to the long time disease buildup since its first introduction in the south Ethiopia.

In the current survey, leaves were generally attacked less severely than fruits. Eshetu (1999) reported similar results on sweet orange trees. Disease severity at Aleta Wendo was very high on both citrus leaves and fruits. At Goro, it was observed that only citrus leaves were affected. However, severity on citrus leaves and fruits varied from district to district. Accordingly, mean incidence values on leaves and fruits at district level were $30.7 \%$ and $47.7 \%$, while severity ratings were $2.4 \%$ and $3.3 \%$, respectively. Eshetu (1999) and Mohammed (2007) also reported the variation of disease severity percentage on leaves and fruits from location to location. Aleta Wendo, Abeshege, Mana, Jimma City, Ginbo, Debre Werk and Kebena were the most seriously affected districts. These districts are located in the south and southwest parts of Ethiopia where the PLFS disease was first introduced in to the country and then spread.

During the survey, farmers in Aleta Wendo stated that symptoms of PLFS disease were first appeared in that area in 1985. Yimenu (1993) reported the first observation of characteristic field symptoms of leaf and fruit spot disease on citrus trees in Aleta Wendo and Dale districts in 1988. According to the farmers, citrus fruit used to be one of their major income sources. They stated that three to four trucks of sweet orange fruits from Aleta Wendo district alone had been supplied to the local markets daily before the PLFS disease affected their citrus plantations. Farmers also indicated that in the past 20 years many citrus trees were abandoned due to PLFS disease, and replaced by other crops like coffee. 
Table 4: Incidence and severity of Pseudocercospora leaf and fruit spot disease in the different districts surveyed in 2012 and 2013 in the main citrus growing regions of Ethiopia

\begin{tabular}{lcccc}
\hline \multirow{2}{*}{ District } & \multicolumn{2}{c}{ Incidence (\%) } & \multicolumn{2}{c}{ Severity (1-5 rating scales) } \\
\cline { 2 - 5 } & Foliage & Fruit & Foliage & Fruit \\
\hline Aleta Wendo & 56.1 & 100 & 3.8 & 5.0 \\
Abeshege & 53.9 & 92.0 & 2.9 & 4.6 \\
Debre Werk & 28.0 & 81.5 & 2.9 & 4.0 \\
Mana & 41.6 & 72.5 & 2.2 & 4.6 \\
Kebena & 50.2 & 72.0 & 2.0 & 4.0 \\
Ginbo & 34.5 & 66.0 & 2.0 & 4.3 \\
Jimma City & 60.4 & 52.0 & 4.0 & 4.6 \\
Shebe Senbo & 14.7 & 50.0 & 1.5 & 3.0 \\
Abaya & 39.2 & 38.8 & 2.4 & 1.5 \\
Gomma & 25.0 & 31.9 & 2.4 & 2.4 \\
Jabitehnan & 21.4 & 29.7 & 2.7 & 3.3 \\
Guangua & 14.9 & 29.1 & 1.9 & 3.0 \\
Mecha & 19.6 & 28.0 & 2.0 & 3.8 \\
Tehuledere & 11.8 & 12.4 & 1.7 & 2.0 \\
Sekoru & 17.5 & 6.8 & 1.8 & 2.0 \\
Goro & 1.6 & 0.0 & 2.0 & 1.0 \\
Adama & 0.0 & 0.0 & 1.0 & 1.0 \\
Adami Tulu Jido Combolcha & 0.0 & 0.0 & 1.0 & 1.0 \\
Boset & 0.0 & 0.0 & 1.0 & 1.0 \\
Dejen & 0.0 & 0.0 & 1.0 & 1.0 \\
Dire Dawa City & 0.0 & 0.0 & 1.0 & 1.0 \\
Erer & 0.0 & 0.0 & 1.0 & 1.0 \\
Guba Lafto & 0.0 & 0.0 & 1.0 & 1.0 \\
Jeju & 0.0 & 0.0 & 1.0 & 1.0 \\
Kalu & 0.0 & 0.0 & 1.0 & 1.0 \\
Kewet & 0.0 & 0.0 & 1.0 & 1.0 \\
Lome & 0.0 & 0.0 & 1.0 & 1.0 \\
Merti & 0.0 & 0.0 & 1.0 & 1.0 \\
\hline
\end{tabular}

\section{PLFS Disease Incidence and Severity on the Different Citrus Species}

The summary results of the surveys that show the disease incidences on the different citrus species are presented in Table 5 . The mean disease incidence was higher on sweet oranges (36.2\% on leaves and $63.8 \%$ on fruits) followed by mandarins $(21.5 \%$ on leaves and $29.4 \%$ on fruits). Disease incidence was relatively lower on lemons $(17.1 \%$ on leaves and $18.0 \%$ on fruits) and limes (16.3\% on leaves but nil on fruits). The disease was not positively identified on sour orange, tangor/tangelo, grapefruit and citron leaves, and on grapefruit and citron fruits. The rate of disease severity followed the same trend as in disease incidence (Table 5). Higher rates of disease severity were recorded on sweet orange (2.6 on leaves and 4.0 on fruits) and mandarin (2.3 on leaves and 3.0 on fruits); but it was less on lemon and lime trees.

Disease incidences on sweet oranges ranged from zero to $76.7 \%$ on leaves and from zero to $100 \%$ on fruits, while disease severity ratings varied from 1.0 to 3.8 on leaves and from 1.0 to 5.0 on fruits (Table 6). The disease prevailed on all sweet orange fruits sampled at citrus orchards in Aleta Wendo, Ginbo, Senbo and Welkite areas. In these areas, the disease severity ratings were also very high (5.0) and PLFS disease caused nearly complete fruit drop. However, many citrus orchards in 16 surveyed areas did not show any incidence of the disease on both leaves and fruits of sweet orange. Sweet orange fruits were more severely affected by the disease than the leaves. Based on the field observations made, among sweet orange varieties Washington Naval was highly attacked by PLFS while Jaffa and Hamlin were less affected.
Among the locations surveyed, only three of them had PLFS disease incidences on mandarin trees (Table 6). Higher disease incidence and severity were recorded at Finote Selam and Chagni in the northwest Ethiopia. No incidence of PLFS disease was observed on fruits at Gibe.

Disease incidences on lemons and limes occurred at Chagni, Ginbo and Gibe orchards (Table 6). Leaf incidences occurred in all of these orchards; but at Gibe orchard no PLFS disease incidence observed on fruits. Similar trend was happened for disease severity ratings for lemon and lime. Based on the results of the survey, lemons seemed relatively more susceptible to PLFS disease than limes. Lemons and limes at Finote Selam were not infected by the disease. Susceptibility was suggested to vary with different periods of the year and with locations (Kuate, 1998).

During the present surveys, no incidence of PLFS disease was observed on grapefruit at Gota and Melkassa, and on citron at Goro and Melkassa orchards. Symptoms of PLFS disease occurred on leaves of sour orange at Lado (Lake Abaya) and Agaro areas; interestingly it was not observed on fruits. This might be due to the antifungal activities of the essential oils of sour orange fruits which prevented the infection of PLFS disease. Jazet Dongmo et al. $(2008,2009)$ reported that essential oils extracted from Citrus latifolia var Tahiti, and $C$. aurantifolia inhibited the growth of $P$. angolensis on artificial medium. Leaf incidence on tangor/tangelo trees was recorded only at Chagni orchard (Table 6).

The results of the surveys showed that citrus species differ in their level of disease resistance. Sweet oranges 
Asmare Dagnew et al.,

and mandarins were more severely affected than tangor/tangelo, lemon and lime. The disease did not affect citron trees at all. Moreover, the disease affected fruits more severely than leaves of the major citrus species. The observed differences in the incidence and severity of PLFS disease among the citrus species, and varieties within a species could be due to the differences in their resistance capabilities. The result was consistent with the findings of various authors (Emechebe, 1981; Kuate, 1998; Seif and Hillocks, 1999; Diallo et al., 2003;
Sci. Technol. Arts Res. J., April-June 2014, 3(2): 04-18

Mohammed, 2007). The variation in resistance between varieties of a species often resides in a physiological or biochemical differences between them (Wutscher, 1997). Sisay (2007) recommended that apart from efficient management practices, farmers should plant more resistant varieties budded on more resistant stocks and adopt a comprehensive integrated approach to disease control involving biological, cultural and chemical methods.

Table 5: Average incidence and severity of Pseudocercospora leaf and fruit spot disease on different citrus species assessed in 2012 and 2013 in the main citrus growing regions of Ethiopia

\begin{tabular}{lcccc}
\hline \multirow{2}{*}{ Citrus species } & \multicolumn{2}{c}{ Incidence (\%) } & \multicolumn{2}{c}{ Severity (1-5 rating scales) } \\
\cline { 2 - 5 } & Foliage & Fruit & Foliage & Fruit \\
\hline Sweet orange & 36.2 & 63.8 & 2.6 & 4.0 \\
Mandarin & 21.5 & 29.4 & 2.3 & 3.0 \\
Lemon & 17.1 & 18.0 & 2.0 & 2.0 \\
Lime & 16.3 & 16.7 & 1.7 & 2.0 \\
Sour orange & 23.3 & 0.0 & 2.0 & 1.0 \\
Tangor/Tangelo & 4.0 & 0.0 & 2.0 & 1.0 \\
Grapefruit & 0.0 & 0.0 & 1.0 & 1.0 \\
Citron & 0.0 & 0.0 & 1.0 & 1.0 \\
\hline
\end{tabular}

Table 6: Incidence and severity of Pseudocercospora leaf and fruit spot disease on each citrus species in the different locations surveyed in 2012 and 2013 in Ethiopia

\begin{tabular}{|c|c|c|c|c|c|}
\hline \multirow{2}{*}{$\begin{array}{c}\text { Citrus } \\
\text { species }\end{array}$} & \multirow{2}{*}{ Location of Orchards } & \multicolumn{2}{|c|}{ Incidence (\%) } & \multicolumn{2}{|c|}{ Severity (1-5 rating scales) } \\
\hline & & Foliage & Fruit & Foliage & Fruit \\
\hline \multirow{25}{*}{ Sweet orange } & Aleta Wendo (Omacho Chawa) & 56.1 & 100 & 3.8 & 5.0 \\
\hline & Ginbo (Megenagna) & 38.0 & 100 & 2.0 & 5.0 \\
\hline & Senbo (Kishe Kosta) & 29.5 & 100 & 2.0 & 5.0 \\
\hline & Welkite (Laygnaw Tatessa) & 76.7 & 100 & 3.0 & 5.0 \\
\hline & Welkite (Jejeba ena Gasorie) & 31.1 & 84.0 & 2.8 & 4.2 \\
\hline & Bebeka & 28.0 & 81.5 & 2.9 & 4.0 \\
\hline & Dilla area (Guangua) & 44.3 & 77.5 & 2.8 & 2.0 \\
\hline & Yebu (Gube Bosoka) & 41.6 & 72.5 & 2.2 & 4.6 \\
\hline & Ginbo (Balewold) & 35.9 & 72.0 & 2.0 & 5.0 \\
\hline & Welkite (Aregita) & 50.2 & 72.0 & 2.0 & 4.0 \\
\hline & Agaro (Agaro town) & 37.5 & 60.0 & 2.5 & 3.0 \\
\hline & Jimma & 60.4 & 52.0 & 4.0 & 4.6 \\
\hline & Agaro (Genji Elbu) & 31.2 & 45.0 & 3.0 & 3.5 \\
\hline & Chagni & 20.0 & 40.0 & 2.0 & 4.0 \\
\hline & Finote Selam & 39.5 & 40.0 & 4.0 & 5.0 \\
\hline & Hayk (Jarre) & 35.4 & 37.3 & 3.0 & 4.0 \\
\hline & Bikolo & 19.6 & 28.0 & 2.0 & 3.0 \\
\hline & Gibe & 25.5 & 27.0 & 2.0 & 2.0 \\
\hline & Agaro (Elbu) & 18.9 & 22.5 & 2.0 & 2.2 \\
\hline & Goro (Adami Wedessa) & 4.9 & No fruit & 2.0 & No fruit \\
\hline & Abadeshka & 0.0 & 0.0 & 1.0 & 1.0 \\
\hline & Erer & 0.0 & 0.0 & 1.0 & 1.0 \\
\hline & Adami Tulu (Ethioflora) & 0.0 & 0.0 & 1.0 & 1.0 \\
\hline & Fetuli & 0.0 & 0.0 & 1.0 & 1.0 \\
\hline & Gota & 0.0 & 0.0 & 1.0 & 1.0 \\
\hline \multirow{11}{*}{ Sweet orange } & Harbu & 0.0 & 0.0 & 1.0 & 1.0 \\
\hline & Melkassa & 0.0 & 0.0 & 1.0 & 1.0 \\
\hline & Merti & 0.0 & 0.0 & 1.0 & 1.0 \\
\hline & Nura Era & 0.0 & 0.0 & 1.0 & 1.0 \\
\hline & Shewarobit & 0.0 & 0.0 & 1.0 & 1.0 \\
\hline & Tibila (Tifhste Genet) & 0.0 & 0.0 & 1.0 & 1.0 \\
\hline & Dire Dawa & 0.0 & 0.0 & 1.0 & 1.0 \\
\hline & Woldiya & 0.0 & 0.0 & 1.0 & 1.0 \\
\hline & Ziway & 0.0 & 0.0 & 1.0 & 1.0 \\
\hline & Dejen (Kurar) & 0.0 & 0.0 & 1.0 & 1.0 \\
\hline & Koka & 0.0 & 0.0 & 1.0 & 1.0 \\
\hline \multirow{4}{*}{ Mandarin } & Finote Selam & 24.6 & 49.0 & 3.0 & 4.0 \\
\hline & Chagni & 19.2 & 39.3 & 2.0 & 4.0 \\
\hline & Gibe & 20.7 & 0.0 & 2.0 & 1.0 \\
\hline & Abadeshka & 0.0 & 0.0 & 1.0 & 1.0 \\
\hline
\end{tabular}




\begin{tabular}{|c|c|c|c|c|c|}
\hline & Gota & 0.0 & 0.0 & 1.0 & 1.0 \\
\hline & Harbu & 0.0 & 0.0 & 1.0 & 1.0 \\
\hline & Hayk (Jarre) & 0.0 & 0.0 & 1.0 & 1.0 \\
\hline & Melkassa & 0.0 & 0.0 & 1.0 & 1.0 \\
\hline & Merti & 0.0 & 0.0 & 1.0 & 1.0 \\
\hline & Nura Era & 0.0 & 0.0 & 1.0 & 1.0 \\
\hline & Tibila (Tifhste Genet) & 0.0 & 0.0 & 1.0 & 1.0 \\
\hline & Dire Dawa & 0.0 & 0.0 & 1.0 & 1.0 \\
\hline & Woldiya & 0.0 & 0.0 & 1.0 & 1.0 \\
\hline & Ziway & 0.0 & 0.0 & 1.0 & 1.0 \\
\hline \multirow{8}{*}{ Lemon } & Chagni & 16.9 & 36.0 & 2.0 & 3.0 \\
\hline & Gibe & 17.2 & 0.0 & 2.0 & 1.0 \\
\hline & Finote Selam & 0.0 & 0.0 & 1.0 & 1.0 \\
\hline & Hayk (Jarre) & 0.0 & 0.0 & 1.0 & 1.0 \\
\hline & Melkassa & 0.0 & 0.0 & 1.0 & 1.0 \\
\hline & Dire Dawa & 0.0 & 0.0 & 1.0 & 1.0 \\
\hline & Woldiya & 0.0 & 0.0 & 1.0 & 1.0 \\
\hline & Ziway & 0.0 & 0.0 & 1.0 & 1.0 \\
\hline \multirow{10}{*}{ Lime } & Chagni & 14.2 & 30.0 & 2.0 & 3.0 \\
\hline & Ginbo (Megenagna) & 28.2 & 20.0 & 2.0 & 2.0 \\
\hline & Gibe & 6.5 & 0.0 & 1.0 & 1.0 \\
\hline & Finote Selam & 0.0 & 0.0 & 1.0 & 1.0 \\
\hline & Goro (Adami Wedessa) & 0.0 & 0.0 & 1.0 & 1.0 \\
\hline & Harbu & 0.0 & 0.0 & 1.0 & 1.0 \\
\hline & Melkassa & 0.0 & 0.0 & 1.0 & 1.0 \\
\hline & Nura Era & 0.0 & 0.0 & 1.0 & 1.0 \\
\hline & Senbo (Kishe Kosta) & 0.0 & 0.0 & 1.0 & 1.0 \\
\hline & Woldiya & 0.0 & 0.0 & 1.0 & 1.0 \\
\hline \multirow{2}{*}{ Grapefruit } & Gota & 0.0 & No fruit & 1.0 & No fruit \\
\hline & Melkassa & 0.0 & 0.0 & 1.0 & 1.0 \\
\hline \multirow{5}{*}{ Tangor/Tangelo } & Chagni & 4.0 & 0.0 & 1.6 & 1.0 \\
\hline & Abadeshka & 0.0 & 0.0 & 1.0 & 1.0 \\
\hline & Melkassa & 0.0 & 0.0 & 1.0 & 1.0 \\
\hline & Merti & 0.0 & 0.0 & 1.0 & 1.0 \\
\hline & Nura Era & 0.0 & 0.0 & 1.0 & 1.0 \\
\hline \multirow{2}{*}{ Sour Orange } & Lake Abaya (Lado) & 34.1 & 0.0 & 2.0 & 1.0 \\
\hline & Agaro (Koye Seja) & 12.5 & 0.0 & 2.0 & 1.0 \\
\hline \multirow{2}{*}{ Citron } & Goro (Adami Wedessa) & 0.0 & 0.0 & 1.0 & 1.0 \\
\hline & Melkassa & 0.0 & 0.0 & 1.0 & 1.0 \\
\hline
\end{tabular}

PLFS Disease Severity in Relation to Agro-Climatic Conditions and Citrus Tree Age

Temperature and elevation of the areas considered in the surveys did not contribute much to the incidence and severity of PLFS disease. High plague of PFLS disease of citrus was recorded at all developmental stages of citrus trees. However, citrus orchards that received high rainfalls exhibited high severity of PLFS disease, conversely those areas that did not exhibit the disease had low annual rainfalls (Table 7); indicating the direct relationship between disease incidence and amount of rainfall. Further studies in controlled environment are needed to validate this observation. Districts with PLFS disease incidences had average minimum and maximum temperatures ranging from 12 to $35^{\circ} \mathrm{C}$ mean annual rainfalls of 500 to $1750 \mathrm{~mm}$, altitudes that varied from 900 to 2000 m.a.s.l, and citrus trees that aged from 2 to 60 years. On the other hand, those districts free from PLFS disease incidences had temperatures ranging from 10 to $37.5^{\circ} \mathrm{C}$, mean annual rainfalls of 316 to $750 \mathrm{~mm}$, altitudes that varied from 1100 to 1760 m.a.s.l, and citrus trees with the age of 3 to 70 years. More severe PLFS disease attacks were recorded in areas with high annual rainfalls like Aleta Wendo, Jimma, Welkite, Yebu, Ginbo and Bebeka. The disease was reported to be more severe during and right after the end of the rainy season, particularly in September and October. These results were consistent with previous reports (Eshetu, 1999; Yigzaw and Gelelbelu, 2002; Mohammed, 2007).

Various authors (Seif and Hillocks, 1993; Eshetu, 1999; Mohammed, 2007) reported that wind-borne conidia of $P$. angolensis infect citrus fruits, leaves and young twigs. Windbreak trees planted around the periphery of the orchards are thought to be the potential sources of the pathogen (Whiteside et al., 1988). Although the use of windbreak trees seems important from agro-ecological point of view and pest trap, field disease control by sanitation and clearing of inoculum source is important (Sierra et al., 1993; Pretorius, 2005).

\section{Isolation and Identification of the Causative Agent}

Isolates grown on PDA medium at $26^{\circ} \mathrm{C}$ from infected leaf and fruit samples were identified based on cultural and morphological characteristics. They were found identical to $P$. angolensis described by different authors (Kirk, 1986; Kuate, 1998; Eshetu, 1999). The mycelium was mostly creamy white or light grey in culture and compact in density. Conidia were born in branched chains of 2-4, hyaline, cylindrical and some of them had from two to four septa. Pathogenicity tests were also conducted on apparently healthy detached leaves, using Koch's method (Kiraly et al., 1974). The same symptoms were observed on artificially inoculated leaves after a week. The same fungus having the same cultural and morphological characteristics was re-isolated from inoculated leaves. 
Table 7: Pseudocercospora leaf and fruit spot disease severity assessed in relation to the agro-climatic conditions of citrus orchards and tree age in the 2012 and 2013 surveys in Ethiopia

\begin{tabular}{|c|c|c|c|c|c|c|}
\hline \multirow[t]{2}{*}{ Districts surveyed } & \multicolumn{2}{|c|}{$\begin{array}{c}\text { Severity } \\
\text { (1-5 rating scale) }\end{array}$} & \multirow{2}{*}{$\begin{array}{c}\text { Average } \\
\text { temperature } \\
\text { range }\left({ }^{\circ} \mathrm{C}\right)\end{array}$} & \multirow{2}{*}{$\begin{array}{l}\text { Mean annual } \\
\text { rainfall (mm) }\end{array}$} & \multirow{2}{*}{$\begin{array}{l}\text { Elevation } \\
\text { (m) }\end{array}$} & \multirow{2}{*}{$\begin{array}{c}\text { Tree age } \\
\text { (year) }\end{array}$} \\
\hline & Foliage & Fruit & & & & \\
\hline Aleta Wendo & 3.8 & 5.0 & $12-26$ & 1400 & 1900 & $2-60$ \\
\hline Jimma City & 4.0 & 4.6 & $14-30$ & 1150 & 1780 & 10 \\
\hline Abeshege & 2.9 & 4.6 & 10.3-25.9 & 1244 & $1830-1860$ & $15-20$ \\
\hline Mana & 2.2 & 4.6 & $11.6-27.1$ & 1640 & 1630 & $7-9$ \\
\hline Ginbo & 2.0 & 4.3 & No data & No data & $1440-1500$ & $4-15$ \\
\hline Debre Werk & 2.9 & 4.0 & $15-30$ & 1750 & $900-1200$ & 22 \\
\hline Kebena & 2.0 & 4.0 & $10-26$ & 1240 & 1780 & 12 \\
\hline Mecha & 2.0 & 3.8 & $12-21$ & 828 & 1900 & $17-28$ \\
\hline Jabitehnan & 2.7 & 3.3 & $14-26$ & No data & 1800 & $19-36$ \\
\hline Guangua & 1.9 & 3.0 & $15-28$ & No data & 1750 & $15-19$ \\
\hline Shebe Senbo & 1.5 & 3.0 & No data & No data & 1440 & $12-30$ \\
\hline Gomma & 2.4 & 2.4 & No data & No data & $1680-2000$ & $6-16$ \\
\hline Sekoru & 1.8 & 2.0 & $15-35$ & 800 & 1100 & $3-14$ \\
\hline Tehuledere & 1.7 & 2.0 & $14-28$ & 500 & 1700 & $10-25$ \\
\hline Abaya & 2.4 & 1.5 & $18-32$ & $900-1000$ & $1280-1680$ & $10-20$ \\
\hline Goro & 2.0 & 1.0 & No data & 1260 & 1860 & 6 \\
\hline Adama & 1.0 & 1.0 & $13-28$ & 750 & 1550 & 7 \\
\hline Adami Tulu & 1.0 & 1.0 & $13-28$ & $543-600$ & $1600-1680$ & $8-34$ \\
\hline Boset & 1.0 & 1.0 & $10-37.5$ & 316 & 1100-1205 & $3-30$ \\
\hline Dejen & 1.0 & 1.0 & No data & No data & 1600 & 18 \\
\hline Dire Dawa & 1.0 & 1.0 & $18-28$ & 595 & 1280 & $25-60$ \\
\hline Erer & 1.0 & 1.0 & $18-27$ & $425-500$ & $1120-1180$ & $3-70$ \\
\hline Guba Lafto & 1.0 & 1.0 & No data & 800 & 1760 & 17 \\
\hline Jeju & 1.0 & 1.0 & $11-36$ & $383-700$ & $1100-1240$ & $3-28$ \\
\hline Kalu & 1.0 & 1.0 & No data & No data & $1560-1600$ & $3-30$ \\
\hline Kewet & 1.0 & 1.0 & $16-30$ & 425 & 1320 & $4-55$ \\
\hline Lome & 1.0 & 1.0 & No data & No data & 1560 & 16 \\
\hline Merti & 1.0 & 1.0 & 11-34 & 383 & 1100 & 30 \\
\hline
\end{tabular}

\section{CONCLUSIONS}

Pseudocercospora leaf and fruit spot disease is one of the crucial constraints to citrus production in many parts of Ethiopia. The production environment seemed to influence the prevalence of the disease. It has widely spread in most citrus producing areas with high rainfalls; but the disease was not observed in the drier parts of the country. Since the last survey conducted in 2001 and 2002, the disease has spread in to new, PLFS disease free citrus producing areas in the northwest and north central parts of the country. The disease caused severe leaf and fruit damages which render significant defoliation and fruit drop. The severity of the disease varied among different citrus species and areas with different agroecologies. Severity increased, in ascending order, for citron, lime, lemon, mandarins, and sweet oranges. Citrus orchards in the south and southwest with high rainfalls were more severely affected by the disease than those in the northwest and central north parts. In some of these areas, complete loss of fruit yield was recorded. Field observations during the surveys indicated that no proper crop management practices were implemented by almost all citrus growers. This has contributed for high disease severity. Results of typical symptoms observed in the field, the macroscopic and microscopic characteristics noticed in the laboratory, and the pathogenicity tests indicated that the causative agent of PLFS disease to be $P$. angolensis. Therefore, due emphasis should be given to the problem and the disease spread has to be ceased.

Citrus producers should be advised to know and maintain the soil nutrient status of their orchards, and to practice general hygiene and sanitary measures such as removal of infected leaves and fruits, pruning of dead branches and twigs, and clearing of neglected orchards to reduce inoculum source. Domestic quarantine is highly required to limit the spread of the disease to new areas through planting materials and/or fruits. Field application of recommended fungicides such as the mixture of benomyl and chlorothalonil could significantly reduce the damage of the disease. Differences in susceptibility were observed among and within species which necessitate studying the reactions of the available varieties in the country to $P$. angolensis. Thus, selection and use of disease resistant/tolerant scion cultivars may be important. Reliable and quick disease identification and monitoring techniques, and integrated disease management strategies need to be in place in the country.

\section{ACKNOWLEDGEMENTS}

The authors acknowledge all respondents for their unreserved cooperation in providing the necessary information, and for allowing us to record disease intensity data and to collect samples from their orchards. The authors also gratefully acknowledge the Ethiopian Institute of Agricultural Research for financial support, and the National Agricultural Biotechnology Program at the Holetta Agricultural Research Center for allowing the microbial biotechnology laboratory for pathogen isolation, identification and pathogenicity test. The first author would like to thank Dr. Edossa Etissa, National Tropical Fruits Research Project Coordinator, and Dr. Getachew Ayana, Director of Melkassa Agricultural Research Center for facilitating financial matters and vehicles for the field 


\section{Asmare Dagnew et al.,}

surveys. The authors are grateful to the Fruits Research Team at Melkassa for their assistances during the field surveys. The authors also thank the Biotechnology Research Team at Holetta for their unreserved support during the laboratory works.

\section{REFERENCES}

Amadi, J.E. (2008). Studies of the etiology of leaf spot of disease of rough lemon (Citrus jambhiri-B. Jamir; $\mathrm{H}$. Jhambhiri). Bio-Research 6:343-345.

Amata, R.L., Otipa, M.J., Waiganjo, M., Wabule, M., Thuranira, E.G., Erbaugh, M. and Miller, S. (2009). Incidence, prevalence and severity of passion fruit fungal diseases in major production regions of Kenya. Journal of Applied Biosciences 20:1146-1152.

Caruso, F.L. and Wilcox, W.F. (1990). Phytophthora cinnamomi as a cause of root rot and dieback of cranberry in Massachusetts. Plant Disease, 74:664-667.

Chung, K.R. and Timmer, L.W. (2009). Citrus diseases exotic to Florida: Phaeoramularia fruit and leaf spot (PFLS). Fact Sheet PP-234. Gainesville, USA: University of Florida. Available online: http://edis.ifas.ufl.edu/pp155. Retrieved October 28, 2011.

CSA (Central Statistical Agency). (2011). Agricultural sample survey: large and medium scale commercial farms. Vol. 8. Statistical Bulletin 505. CSA, Addis Ababa, Ethiopia.

CSA (Central Statistical Agency). (2012). Agricultural sample survey: report on area and production of major crops for private peasant holding, Vol. 1. Statistical Bulletin. CSA, Addis Ababa, Ethiopia.

Davies, F.S. and Albrigo, L.G. (1994). Citrus. Wallingford, UK: CAB International. 254p.

Dewdney, M. and Timmer, L.W. (2009). Citrus production and diseases in Ghana. In: Citrus Industry. Available online: http://www.crec.ifas.ufl.edu/academics/faculty/dewdney/P DF/ Ghanatripstory.pdf. Retrieved February 19, 2014

Diallo, M.T.S., Camara, M., Diane, M.Y., Bah, A.S., Pivi, A.M. and Traore, L. (2003). Towards control of citrus cercosporiose in Guinea. Fruits 58:329-344.

Droby, S., Chalutz, E. and Wilson, C.L. (1991). Antagonistic microorganisms as biological control agents of postharvest diseases of fruits and vegetables. Postharvest News and Information 2:169-173.

Emana Getu, Eshetu Ahmed and Mohammed Yesuf. (2003). Woolly white fly: a new pest of citrus orchards in Ethiopia. The 11th Annual Conference of the Crop Protection Society of Ethiopia (CPSE), 5-6 June 2003, Addis Ababa, Ethiopia (Abstract).

Emechebe, A.M. (1981). Brown spot disease of Citrus caused by Phaeoisariopsis sp. Annals of Applied Biology 97:257-262.

Eshetu Derso. (1997). Leaf and fruit spot: a new disease of citrus in Ethiopia. In: Proceedings of the 7th Annual Conference, 27-28 April 1995, Crop Science Society of Ethiopia, Addis Ababa, Ethiopia. pp. 215-221.

Eshetu Derso. (1999). Occurrence, prevalence and control methods of Phaeoramularia leaf and fruit spot disease of citrus in Ethiopia. Fruits 54:225-232.

Eshetu Derso and Sijam, K. (2007). Citrus canker: a new disease of Mexican lime (Citrus aurantifolia) and sour orange (C. aurantium) in Ethiopia. Fruits, 62:89-98.
Sci. Technol. Arts Res. J., April-June 2014, 3(2): 04-18

Ezeibekwe, I.O. (2011). Study of citrus disease prevalence on four citrus varieties at the National Institute of Horticultural Research (NIHORT) Mbato, Okigwe, Imo State, Nigeria. African Journal of Plant Science 5:360364.

Ferdu Azerefegne, Mohammed Dawd, Difabachew Belay and Bezawork Mekonnen. (2009). Review of entomological research on fruit crops in Ethiopia. In: Abraham Tedesse (Ed.), Increasing Crop Production through Improved Plant Protection, Vol. 2. Plant Protection Society of Ethiopia (PPSE), EIAR, Addis Ababa. pp. 69-92.

Fry, W.E. (1977). Management with chemicals. In: Horsfall, J.G. and Cowling, E.B. (Eds.), Plant Disease: An Advanced Treatise. Vol. I. How Disease Is Managed. Academic Press Inc., New York. pp. 213-332.

Garnsey, S.M., Gottwald, T.R. and Yokomi, R.K. (1998). Control strategies for citrus tristeza virus. In: Hadidi, A., Khetarpal, R.K. and Koganezawa, H. (Eds.), Plant Virus Disease Control. American Phytopathological Society, St. Paul, Minnesota. pp. 639-658.

Graham, J.H. and Timmer, L.W. (1994). Phytophthora diseases of citrus. SL127, Reviewed June 2003. Institute of Food and Agricultural Sciences (IFAS), University of Florida, Gainesville, Florida. Available online: http://orange.ifas.ufl.edu/mg/mg_compendium/pdffiles/ch/ CH08700.pdf. Retrieved April 8, 2014.

Hughes, G., Gottwald, T.R. and Yamamura, K. (2002). Survey methods for assessment of citrus tristeza virus incidence in urban citrus populations. Plant Disease 86:367-372.

Ippolito, A., Nigro, F. and Lima, G. (1996). Influence of the scion on the response of sour orange rootstock to experimentally induced Phytophthora gummosis and root rot. Proceedings of the International Society of Citriculture 1:385-388.

Jazet Dongmo, P.M., Tatsadjieu, N.L., Tchinda Sonwa, E., Kuate, J., Amvam Zollo, P.H. and Menut, C. (2008). Antiradical potential and antifungal activities of essential oils of the leaves of Citrus latifolia against Phaeoramularia angolensis. African Journal of Biotechnology 7:40454050.

Jazet Dongmo, P.M., Tatsadjieu, N.L., Tchinda Sonwa, E., Kuate, J., Amvam Zollo, P.H. and Menut, C. (2009). Essential oils of Citrus aurantifolia from Cameroon and their antifungal activity against Phaeoramularia angolensis. African Journal of Agricultural Research 4:354-358.

Kassahun Tessega, Temam Hussien and Sakhuja, P.K. (2006). Management of Phaeoramularia fruit and leaf spot disease of citrus in Ethiopia. Agricultura Tropica et Subtropica, 39:242-248.

Kiraly, Z., Klement, Z., Solymosy, F. and Voros, J. (1974). Methods in plant pathology. Rev. Ed., Elsevier Scientific Publishing Company, New York, USA. pp. 135-136.

Kirk, P.M. (1986). Phaeoramularia angolensis. CMI Descriptions of Pathogenic Fungi and Bacteria, No. 863. Mycopathologia 94:177-178.

Kuate, J. (1998). Citrus leaf and fruit spot disease caused by Phaeoramularia angolensis. Cahiers Agricultures 7:121129.

Kuate, J. (1999). Fruit and leaf spot disease caused by Phaeoramularia angolensis: a threat to citrus production. Research and Methods, FRuiTROP, No. 61. 
Asmare Dagnew et al.,

Kuate, J., Foure, E., Foko, J., Ducelier, D. and Tchio, F. (2002). Citrus phaeoramulariosis due to Phaeoramularia angolensis in Cameroon: parasitic expression at different altitudes. Fruits 57:207-218.

Kuate, J., Jazet Dongmo, P.M., Ducelier, D., Damesse, F., Menut, C. and Bessiere, J.M. (2003). Effect of citrus leaf spot disease (Phaeoramularia angolensis) on the content and chemical composition of essential oils from orange peel. Fruits 58:143-149.

Lemma Gebeyehu. (1994). Research on fruit crops diseases. In; Herath, E. and Lemma Dessalegn (Eds.), Horticulture Research and Development in Ethiopia. Proceedings of the 2nd National Horticultural Workshop of Ethiopia, 1-3 December 1992, Addis Ababa. pp. 232-242.

McDonald, B. and Linde, C. (2002). Pathogen population genetics, evolutionary potential, and durable resistance. Annual Review of Phytopathology 40:349-379.

Mohammed Yesuf and Getachew Ayana. (1995). A review of vegetables and fruit crops diseases research: achievements and prospects. In: Habtu Assefa (Ed.), Proceedings of the 25th Anniversary of Nazareth Agricultural Research Center: 25 Years of Experience in Lowland Crops Research, 20-23 September 1995. Nazareth Agricultural Research Center, Nazareth, Ethiopia. pp. 129-140.

Mohammed Yesuf. (2007). Distribution and management of Phaeoramularia leaf and fruit spot disease of citrus in Ethiopia. Fruits 62:99-106.

Mohammed Yesuf. (2013). Pseudocercospora leaf and fruit spot disease of citrus: achievements and challenges in the citrus industry: A review. Agricultural Sciences 4(7):324-328.

Ndo, E.G.D., Bella-Manga, F., Ndindeng, S.A., NdoumbeNkeng, M., Fontem, A.D. and Cilas, C. (2010). Altitude, tree species and soil type are the main factors influencing the severity of Phaeoramularia leaf and fruit spot disease of citrus in the humid zones of Cameroon. European Journal of Plant Pathology 128:385-397.

Oudemans, P.V. (1999). Phytophthora species associated with cranberry root rot and surface irrigation water in New Jersey. Plant Disease 83:251-258.

Pretorius, M.C., Crous, P.W., Groenewald, J.Z. and Braun, U. (2003). Phylogeny of some cercosporoid fungi from Citrus. Sydowia, 55:286-305.

Pretorius, M.C. (2005). Epidemiology and control of Pseudocercospora angolensis fruit and leaf spot disease on citrus in Zimbabwe, MSc Thesis, Stellenbosch University, South Africa.

Salerno, M. and Cutuli, G. (1982). The management of fungal and bacterial disease of citrus in Italy. Proceedings of the International Society of Citriculture1:360-362.

Schubert, T.S. and Miller, J.W. (2000). Bacterial citrus canker. Florida Department of Agricultural Conservation Service (FDACS), Division of Plant Industry, Plant Pathology Circular 377 revised. Gainesville, Florida.
Sci. Technol. Arts Res. J., April-June 2014, 3(2): 04-18

Seif, A.A and Hillocks, R.J. (1993). Phaeoramularia fruit and leaf spot of citrus with special reference to Kenya. International Journal of Pest Management 39:44-50.

Seif, A.A. and Hillocks, R.J. (1999). Reaction of some citrus cultivars to Phaeoramularia fruit and leaf spot in Kenya. Fruits 54:323-329.

Seifu Gebre-Mariam. (2003). Status of commercial fruit production in Ethiopia. Ethiopian Agricultural Research Organization (EARO), Addis Ababa, Ethiopia.

Sierra, C.C., Molina, E.B., Zaldivar, C.P., Flores, L.P. and Garcia, L.P. (1993). Effect of harvesting season and postharvest treatments on storage life of Mexican limes (Citrus aurantifolia Swingle). Journal of Food Quality 16:339-354.

Sisay Bekele Mekbib. (2007). Identification of citrus (Citrus sinensis) postharvest pathogens from Ethiopia and their control. PhD Thesis, University of Pretoria, South Africa.

Taylor, M.S. (1997). The future of citrus fruits in the fresh produce world: a discerning customer's view. Proceedings of the International Society of Citriculture, The 8th International Citrus Congress 1:15-18.

Tesfaye Tedila and Habtu Assefa. (1985). A review of research activities on fruit crop diseases in Ethiopia. In: Tsedeke Abate (Ed.), Proceedings of the 1st Ethiopian Crop Protection Symposium, 4-7 February 1985, Addis Ababa, Ethiopia. pp. 263-276.

Timmer, L.W., Garnsey, S.M. and Broadbent, P. (2003). Diseases of citrus. In: Ploetz, R.C. (Ed.), Diseases of Tropical Fruit Crops, CAB International, Wallingford, UK. pp. 163-195.

Tripathi, P. and Dubey, N.K. (2004). Exploitation of natural products as an alternative strategy to control postharvest fungal rotting of fruit and vegetables. Postharvest Biology and Technology 32:235-245.

Tsedeke Abate. (1983). Insecticides for the control of red scale Aonidiella aurantii (Maskell) (Homoptera: Diaspididae) in the Awash Valley, Ethiopia. Ethiopian Journal of Agricultural Science 5(1):32-42.

Tsedeke Abate. (1991). Entomophagous arthropods on Ethiopia: a catalogue. Technical Manual No. 4. Institute of Agricultural Research (IAR), Addis Ababa.

Wilson, G.L., Boyette, M.D. and Estes, E.A. (1995). Postharvest handling and cooling of fresh fruits, vegetables, and flowers for small farms. Horticulture Information Leaflet. North Carolina State University College of Agriculture, Cooperative Extension Service, USA. Available online: http://www.ces.ncsu.edu/hil/hil800.html. Retrieved April 7, 2014.

Wutscher, H.K. (1997). Soil acidity and citrus blight. Communications in Soil Science and Plant Analysis 28:603-612.

Yigzaw Dessalegn and Gelelbelu Girma. (2002). Phaeoramularia angolensis: a citrus disease in Northwest Ethiopia. AgriTopia 17(1):12-13.

Yimenu J. (1993). Preliminary survey report on leaf spot disease of citrus in Sidamo. Field Trip Report, Coffee Development Authority, Addis Ababa, Ethiopia. 